\title{
Effects of phytonutrients alone or in combination with monensin on productivity in lactating dairy cows
}

\author{
J. Oh, ${ }^{*}$ M. Harper, ${ }^{*}$ C. H. Lang, † E. H. Wall, $\ddagger$ and A. N. Hristov*1 \\ *Department of Animal Science, The Pennsylvania State University, University Park 16802 \\ †Department of Cellular and Molecular Physiology, The Pennsylvania State University, Hershey 17033 \\ ¥Pancosma S.A., CH-1280, Geneva, Switzerland
}

\begin{abstract}
This experiment was conducted to investigate the effects of phytonutrients, compared with monensin as a positive control, on productivity, milk fatty acids, fat mobilization, and blood cells in lactating dairy cows. Thirty-six Holstein cows were used in a 9-wk randomized complete block design study. Following a 2-wk covariate period, cows were blocked by days in milk, parity, and milk yield and randomly assigned to 1 of 3 treatments (12 cows/treatment): $450 \mathrm{mg} / \mathrm{cow}$ per day of monensin (MO), $250 \mathrm{mg} / \mathrm{cow}$ per day of capsicum plus $450 \mathrm{mg} / \mathrm{cow}$ per day of MO (MOCAP), and $1,000 \mathrm{mg} / \mathrm{cow}$ per day of a mixture of cinnamaldehyde, eugenol, and capsicum (CEC). Dry matter intake and milk yield were not affected by treatment. Supplementation of CEC increased feed efficiency compared with MO, but did not affect feed efficiency on an energy-corrected milk basis. Milk composition (fat, protein, and lactose), milk fatty acid profile, and blood concentrations of nonesterified fatty acids and $\beta$-hydroxybutyrate were also not affected by treatment. The expression of hormone-sensitive lipase in adipose tissues tended to increase for MOCAP compared with MO. Counts of total white blood cell, neutrophils, lymphocytes, eosinophils, and basophils were not affected by treatment, although monocytes count tended to be decreased by CEC. Treatments had no effect on red blood cells, hemoglobin, and platelets. Results indicate that dietary supplementation of CEC and capsicum had no production or other effects in dairy cows, compared with MO, except CEC increased feed efficiency and tended to decrease blood monocytes count.
\end{abstract}

Key words: phytonutrient, milk yield, feed efficiency, dairy cow

Received January 13, 2018.

Accepted April 3, 2018.

${ }^{1}$ Corresponding author: anh13@psu.edu

\section{INTRODUCTION}

Phytonutrients (PN) are plant-derived bioactive compounds produced by the secondary metabolism in plants (Patra, 2012). It is well known that PN have antimicrobial effects and are used as self-defense agents in plants (Cowan, 1999). In studies with ruminants, PN have been used to modify ruminal fermentation, increase nutrient use efficiency, and enhance animal productivity (Calsamiglia et al., 2007). Some phenolic PN, such as cinnamaldehyde (CIN), eugenol (EUG), and capsicum (CAP), decreased acetate and increased propionate concentrations in ruminal contents of cattle (Cardozo et al., 2006; Yang et al., 2010a). Propionate improves dietary energy use efficiency by increasing energy supply through gluconeogenesis, and increased propionate concentration is associated with decreased methane production in ruminants (Aschenbach et al., 2010; Janssen, 2010). These ruminal effects of PN are similar to those of conventional rumen modifiers such as monensin (MO). As an ionophoric antibiotic, MO is known to selectively inhibit gram-positive bacteria, which results in decreased acetate and increased propionate concentrations in the rumen (Russell and Strobel, 1989).

In addition to ruminal effects, PN may have postruminal effects (Oh et al., 2017a). In studies with nonruminants, capsaicin, the main active compound in CAP, binds to its receptor in the intestine to induce host-mediated responses (Holzer, 2011). Capsaicin or CAP exhibited pro- and anti-inflammatory effects (Lee et al., 2011; Liu et al., 2013) and stimulated fat mobilization (Azhar et al., 2016) and digestive enzyme secretion (Srinivasan, 2016) in chicken, pigs, and rats. These effects could be expected in ruminants if CAP bypasses the rumen. In a study with dairy cows, abomasal infusion of CAP modulated the immune system by increasing $\mathrm{T}$ helper cells (Oh et al., 2013). Dietary supplementation of unprotected CAP enhanced energy availability by increasing fat mobilization without affecting ruminal fermentation (Oh et al., 2015). Ruminal escape of capsaicin was reportedly estimated between 
15 and $33 \%$ depending on the dose amount in dairy cows (Oh et al., 2016).

Therefore, we hypothesized that PN may, due to their ruminal and postruminal effects, enhance animal productivity by improving nutrient use efficiency. The study investigated the ruminal effects of phenolic PN (CIN, EUG, and CAP) in comparison with $\mathrm{MO}$ and potential postruminal effects of CAP when supplemented together with MO. The objective of our study was to investigate the effects of PN alone or in combination with MO on feed intake, milk yield and composition, fat mobilization, and blood cells in lactating dairy cows.

\section{MATERIALS AND METHODS}

\section{Animals and Treatments}

The Pennsylvania State University Animal Care and Use Committee approved all procedures used in this experiment. The experiment was conducted at The Pennsylvania State University's Dairy Teaching and Research Center (University Park). The experiment involved 36 lactating Holstein cows (average milk yield $=46 \pm 8.8 \mathrm{~kg} ; \mathrm{BW}=676 \pm 75.8 \mathrm{~kg}$; and 120 \pm 23.1 DIM at the beginning of the experiment) arranged in a randomized complete block design. Cows were housed in a sand-bedded freestall barn equipped with the Calan Broadbent Feeding System (American Calan Inc., Northwood, NH) for measuring individual feed intake. Cows were trained to use the Calan system before the beginning of the experiment and had free access to drinking water. The experiment lasted $9 \mathrm{wk}$, including a 2-wk covariate period followed by a 7 -wk experimental period that included $3 \mathrm{wk}$ for diet adaptation and $4 \mathrm{wk}$ for data and sample collection. During the covariate period, cows were fed the herd diet, which consisted of (\% of DM) $39.0 \%$ corn silage, $16.6 \%$ alfalfa haylage, $2.5 \%$ grass hay, $8.3 \%$ ground and $1.6 \%$ cracked corn, $7.5 \%$ solvent-extracted canola meal, $7.4 \%$ candy by-product meal, $5.8 \%$ heat-treated whole soybeans, $5 \%$ cane molasses, $3.3 \%$ cottonseed hulls, $2.7 \%$ mineral and vitamin premix, and $0.3 \%$ Optigen (Alltech Inc., Nicholasville, KY) as a slow-release urea. The covariate diet contained (\% of DM) $14.9 \% \mathrm{CP}, 31.2 \% \mathrm{NDF}$, $21.9 \% \mathrm{ADF}, 44.4 \% \mathrm{NFC}$, and $1.56 \mathrm{Mcal} / \mathrm{kg}$ of $\mathrm{NE}_{\mathrm{L}}$. The experimental diet (Table 1) was formulated to meet or exceed, based on NRC (2001), the nutrient requirements of the cows based on their average DMI $(30.2 \mathrm{~kg} / \mathrm{d}), \mathrm{BW}(671 \mathrm{~kg})$, and milk yield $(47.1 \mathrm{~kg} / \mathrm{d})$ and composition $(3.80 \%$ milk fat, $3.20 \%$ true protein, and $4.78 \%$ lactose) during the covariate period.

Cows were blocked in blocks of 3 based on DIM, parity, and milk yield during the covariate periods. Cows within a block were randomly assigned to 1 of the following treatments (12 cows/treatment): $450 \mathrm{mg} / \mathrm{d}$ of MO (Rumensin, Elanco Animal Health, Greenfield, IN), $450 \mathrm{mg} / \mathrm{d}$ of MO plus $250 \mathrm{mg} / \mathrm{d}$ of a product containing $20 \%$ of CAP (XTRACT CapsXL, Pancosma, Geneva, Switzerland; MOCAP), and 1,000 mg/d of a mixture of $5.5 \%$ of CIN, $9.5 \%$ of EUG, and $3.5 \%$ of CAP (XTRACT Ruminant, Pancosma; CEC). Doses of $\mathrm{PN}$ were determined based on previous studies (Oh et

Table 1. Ingredient and chemical composition of the basal diet fed during the experiment

\begin{tabular}{|c|c|}
\hline Item & Measurement \\
\hline \multicolumn{2}{|l|}{ Ingredient, $\%$ of diet DM } \\
\hline Corn silage $^{1}$ & 41.0 \\
\hline Haylage $^{2}$ & 13.0 \\
\hline Grass hay & 5.00 \\
\hline Whole cottonseed & 4.00 \\
\hline Corn grain, ground & 9.30 \\
\hline Soybean seeds, whole heated ${ }^{3}$ & 7.00 \\
\hline Canola meal $^{4}$ & 8.70 \\
\hline Soybean meal ${ }^{5}$ & 5.00 \\
\hline Molasses $^{6}$ & 5.00 \\
\hline Vitamin and mineral premix ${ }^{7}$ & 2.00 \\
\hline \multicolumn{2}{|c|}{ Composition, $\%$ of DM (or as indicated) } \\
\hline $\mathrm{CP}^{8}$ & 16.4 \\
\hline $\mathrm{RDP}^{9}$ & 10.4 \\
\hline RUP $^{9}$ & 6.0 \\
\hline $\mathrm{NDF}^{8}$ & 32.1 \\
\hline $\mathrm{ADF}^{8}$ & 21.2 \\
\hline $\mathrm{NE}_{\mathrm{L}}, \mathrm{Mcal} / \mathrm{kg}^{8}$ & 1.55 \\
\hline $\mathrm{Ca}^{8}$ & 0.7 \\
\hline $\mathrm{P}^{8}$ & 0.4 \\
\hline $\mathrm{NFC}^{9}$ & 43.1 \\
\hline Average $\mathrm{NE}_{\mathrm{L}}$ balance ${ }^{10} \mathrm{Mcal} / \mathrm{d}$ & $(3.6,2.1,0.8)$ \\
\hline Average MP balance, ${ }^{10} \mathrm{~g} / \mathrm{d}$ & $(213,109,68.0)$ \\
\hline
\end{tabular}

${ }^{1}$ Corn silage was $39.5 \% \mathrm{DM}$ and contained (DM basis) $6.8 \% \mathrm{CP}, 38.1 \%$ $\mathrm{NDF}$, and $34.5 \%$ starch.

${ }^{2}$ Haylage was $36.8 \%$ DM and contained (DM basis) $20.2 \% \mathrm{CP}$ and $45.0 \%$ NDF.

${ }^{3}$ Soybean seeds contained (DM basis) $37.4 \% \mathrm{CP}$.

${ }^{4}$ Canola meal contained (DM basis) $42.4 \% \mathrm{CP}$.

${ }^{5}$ Soybean meal contained (DM basis) $46.6 \% \mathrm{CP}$.

${ }^{6}$ Molasses (Westway Feed Products, Tomball, TX) contained (DM basis) $3.9 \% \mathrm{CP}$ and $66 \%$ total sugar.

${ }^{7}$ The premix (Cargill Animal Nutrition, Cargill Inc., Roaring Spring, PA) contained (\%, as-is basis) trace mineral mix, $1.88 ; \mathrm{MgO}(54 \%$ $\mathrm{Mg}$ ), 8.0; $\mathrm{NaCl}, 24.9$; vitamin ADE premix (Cargill Animal Nutrition, Cargill Inc.), 0.41; limestone, 36.8; selenium, 0.13; and dry corn distillers grains with solubles, 29.0. Ca, $14.4 \%$; P, 0.75\%; Mg, 2.48\%; K, $0.28 \%$; S, 0.50\%; Se, $12.8 \mathrm{mg} / \mathrm{kg}$; Cu, $651 \mathrm{mg} / \mathrm{kg}$; Zn, 3,433 mg/kg; Fe, $798 \mathrm{mg} / \mathrm{kg}$, vitamin A, 195,290 IU/kg; vitamin D, 62,500 IU/kg; and vitamin E, 1,863 IU/kg.

${ }^{8}$ Values calculated using the chemical analysis (Cumberland Valley Analytical Services Inc., Maugansville, MD) of the ingredients of the diets.

${ }^{9}$ Estimated based on NRC (2001).

${ }^{10}$ Estimated based on NRC (2001) using actual DMI, milk yield, milk composition, and $\mathrm{BW}$ of the cows throughout the trial (monensin, monensin plus capsicum, and cinnamaldehyde, eugenol, and capsicum, respectively). 
al., 2015; Oguey and Wall, 2016). Cows were ad libitum fed the basal diet once daily in the morning, targeting $10 \%$ refusals. Treatments were top-dressed, mixed with a portion (approximately $500 \mathrm{~g}$ ) of the TMR. All cows were milked twice daily at 0600 and $1800 \mathrm{~h}$.

\section{Sampling and Analyses}

Individual feed intake, milk yield, and $\mathrm{BW}$ of the cows (AfiFarm 3.04E scale system; S.A.E. Afikim, Rehovot, Israel) were recorded daily during the entire experiment. Weekly composited samples of the TMR and refusals were prepared from subsamples collected twice weekly. Forages and concentrate feeds were sampled weekly. Composite samples of the TMR, forages, and concentrates were oven-dried at $65^{\circ} \mathrm{C}$ to constant weight and ground through a 1-mm sieve before being analyzed for CP (AOAC International, 2000), NDF (Van Soest et al., 1991), ADF (AOAC International, 2000), ether extract (AOAC International, 2006), Ca (AOAC International, 2000), P (AOAC International, 2000), and estimated NFC (NRC, 2001) and $\mathrm{NE}_{\mathrm{L}}$ (NRC, 2001) by Cumberland Valley Analytical Services (Maugansville, MD). Analysis of OM was conducted by ashing the TMR samples for $4 \mathrm{~h}$ at $600^{\circ} \mathrm{C}$.

Samples for milk composition were collected from evening and morning milkings in wk 2 of the covariate period and wk 4, 5, and 6 of the experimental period. One set of milk samples was preserved with 2-bromo2-nitropropane-1,3 diol and submitted to Dairy One laboratory (Ithaca, NY) for analysis of milk fat, true protein, lactose, SCC, and MUN using infrared spectroscopy (MilkoScan 4000; Foss Electric, Hillerød, Denmark). Milk composition data were weighted for the corresponding evening and morning milk yields. A second set of milk samples was collected without preservative and frozen at $-20^{\circ} \mathrm{C}$ for milk fatty acids analysis. Milk samples were composited by cow based on milk yield at the sampling days and analyzed for milk fatty acids following the procedure described by Rico and Harvatine (2013).

Blood samples were collected from the coccygeal tail vein or artery at $2 \mathrm{~h}$ after feeding on $1 \mathrm{~d}$ in wh 5 and 6 of the experimental period for hematology, fatty acids, and BHB analyses. Blood samples (approximately 10 $\mathrm{mL}$ ) were collected into evacuated tubes containing EDTA (BD Biosciences, Franklin Lakes, NJ), kept refrigerated at $4^{\circ} \mathrm{C}$, and analyzed for hematology on the same day. The analysis included red blood cell count, hemoglobin, hematocrit, platelet count, mean platelet volume, and total white blood cell count, including total count for neutrophils, lymphocytes, monocytes, eosinophils, and basophils using an automated hematology analyzer (HemaVet; Drew Scientific, Oxford, CT). A separate set of blood samples was collected into evacuated tubes containing EDTA (BD Biosciences). Blood plasma was separated by centrifugation at $1,500 \times g$ at $4^{\circ} \mathrm{C}$ for $15 \mathrm{~min}$ and stored at $-80^{\circ} \mathrm{C}$ for fatty acids and BHB analyses. Enzymatic colorimetric methods were used for blood fatty acids and BHB [NEFA-HR(2) and Autokit 3-HB, respectively, Wako Diagnostics, Mountain View, CA]. The minimum detectable levels of the methods were $0.0014 \mu \mathrm{mol} / \mathrm{L}$ (oleic acid equivalent) and $3 \mu \mathrm{mol} / \mathrm{L}$ for fatty acids and BHB, respectively.

Adipose tissue biopsies (approximately $1 \mathrm{~g}$ ) were collected from the tail head region (Smith and McNamara, 1989) on $1 \mathrm{~d}$ in wk 7 of the experimental period for analysis of hormone-sensitive lipase (HSL). Adipose tissue was immediately placed in Trizol reagent (Qiagen, Valencia, CA) and stored at $-80^{\circ} \mathrm{C}$. Western blot analysis was performed using the protein isolation procedure as described by the manufacturer (https:// tools.thermofisher.com/content/sfs/manuals/trizol _reagent.pdf). The protein concentration of each tissue homogenate was quantified (Bio-Rad Protein Assay, Hercules, CA), and SDS-PAGE was performed using equal amounts of total protein per sample. Each polyvinylidene difluoride membrane was stained with Ponceau S (Aqua Solutions, Deer Park, TX) to verify equal protein loading. Thirty micrograms of total protein extract was separated on a 10\% SDS-PAGE gel. Blots were then blocked in $5 \%$ nonfat dry milk and incubated overnight with primary antibody for HSL (Cell Signaling Technology, Beverly, MA; \#4107; 1:1,000 dilution) at $4^{\circ} \mathrm{C}$. Blots were washed with an appropriate secondary antibody (horseradish peroxidase-conjugated goat anti-rabbit IgG; 1:2,000 dilution) and processed for protein detection using Super Signal chemiluminescent substrate (Thermo Fisher Scientific, Waltham, MA) according to the manufacturer's instructions (https:// assets.thermofisher.com/TFS-Assets/LSG/manuals/ MAN0015920_2162617_SuperSigWestPicoPLUS _Chemil_Substr_UG.pdf). Blots were imaged using the FluorChem (ProteinSimple, San Jose, CA), and densities in the linear range were quantified using ImageJ (NIH, Bethesda, MD). This analysis was conducted only for MO and MOCAP to investigate the effect of CAP on HSL.

\section{Statistical Analysis}

All data were analyzed using the MIXED procedure of SAS 9.3 (SAS Institute Inc., Cary, NC). Outliers were removed with the REG procedure of SAS based on an absolute Studentized residual value $>3$. Data were tested for normality using the UNIVARIATE 
Table 2. Effect of phytonutrients on production and milk composition in dairy cows

\begin{tabular}{|c|c|c|c|c|c|}
\hline \multirow[b]{2}{*}{ Item } & \multicolumn{3}{|c|}{ Treatment $^{1}$} & \multirow[b]{2}{*}{$\mathrm{SEM}^{2}$} & \multirow{2}{*}{$\frac{P \text {-value }}{\text { Treatment }}$} \\
\hline & MO & MOCAP & $\mathrm{CEC}$ & & \\
\hline DMI, kg/d & 31.4 & 31.2 & 30.3 & 0.52 & 0.26 \\
\hline Milk yield, $\mathrm{kg} / \mathrm{d}$ & 46.3 & 48.3 & 47.7 & 0.81 & 0.18 \\
\hline Feed efficiency, ${ }^{3} \mathrm{~kg} / \mathrm{kg}$ & $1.48^{\mathrm{b}}$ & $1.55^{\mathrm{ab}}$ & $1.58^{\mathrm{a}}$ & 0.028 & 0.04 \\
\hline Milk fat, $\%$ & 4.06 & 4.00 & 4.15 & 0.134 & 0.73 \\
\hline Yield, kg/d & 1.95 & 1.94 & 1.98 & 0.070 & 0.93 \\
\hline $\mathrm{ECM}^{4}{ }^{4} \mathrm{~kg} / \mathrm{d}$ & 45.7 & 46.7 & 46.0 & 1.54 & 0.89 \\
\hline ECM feed efficiency & 1.47 & 1.50 & 1.54 & 0.052 & 0.67 \\
\hline Milk true protein, $\%$ & 2.99 & 2.99 & 2.99 & 0.025 & 0.98 \\
\hline Yield, kg/d & 1.44 & 1.46 & 1.41 & 0.031 & 0.46 \\
\hline Milk lactose, $\%$ & 4.79 & 4.81 & 4.81 & 0.030 & 0.82 \\
\hline Yield, kg/d & 2.33 & 2.35 & 2.28 & 0.060 & 0.74 \\
\hline $\mathrm{TS}, \%$ & 11.6 & 11.5 & 11.7 & 0.13 & 0.75 \\
\hline Milk $\mathrm{NE}_{\mathrm{L}}, \mathrm{Mcal} / \mathrm{d}$ & 34.1 & 34.8 & 34.3 & 1.15 & 0.89 \\
\hline MUN, mg/100 mL & 12.0 & 12.2 & 12.2 & 0.27 & 0.89 \\
\hline $\mathrm{SCC}, \times 10^{3}$ cells $/ \mathrm{mL}$ & 53.4 & 89.2 & 140 & 56.83 & 0.42 \\
\hline $\mathrm{BW}, \mathrm{kg}$ & 701 & 696 & 699 & 3.7 & 0.61 \\
\hline
\end{tabular}

a,b Within a row, means without a common superscript letter differ $(P<0.05)$.

${ }^{1} \mathrm{MO}=450 \mathrm{mg} / \mathrm{d}$ monensin; MOCAP $=450 \mathrm{mg} / \mathrm{d}$ of $\mathrm{MO}$ and $250 \mathrm{mg} / \mathrm{d}$ of capsicum; $\mathrm{CEC}=1,000 \mathrm{mg} / \mathrm{d}$ of a blend of cinnamaldehyde, eugenol, and capsicum.

${ }^{2}$ Highest SEM shown; $\mathrm{n}=137$ for DMI, milk yield, feed efficiency, and BW, $\mathrm{n}=36$ for BW change, and $\mathrm{n}=$ 108 for all other variables ( $\mathrm{n}$ represents number of observations used in the statistical analysis).

${ }^{3}$ Milk yield $\div$ DMI.

${ }^{4}$ Energy-corrected milk $(\mathrm{kg} / \mathrm{d})=$ milk yield $(\mathrm{kg} / \mathrm{d}) \times(383 \times \%$ fat $+242 \times \%$ true protein $+165.4 \times \%$ lactose $+20.7) \div 3,140$ (Sjaunja et al., 1990).

procedure of SAS. Data for hematology were log transformed because the $W$ statistic of the Shapiro-Wilk test was $<0.05$; all other data were normally distributed.

Weekly averaged data for DMI, milk yield and composition, calculated feed efficiency, and BW and the hematology, blood fatty acids, and BHB data were analyzed with week as repeated measure assuming an AR(1) covariance structure. The statistical model included week, treatment, treatment $\times$ week interaction, and the covariate term. The covariate term was used only for DMI, milk yield and composition, calculated feed efficiency, and BW in the statistical model. Block and block $\times$ treatment were assumed as random effects, whereas treatment, week, and week $\times$ treatment were fixed effects. Data for HSL and milk fatty acids were analyzed with the same model, excluding week and treatment $\times$ week interaction.

Where the main effect of treatment was significant, means were separated by pairwise $t$-test (pdiff option of PROC MIXED). Statistical differences were declared at $P<0.05$. Differences between treatments at $0.05 \leq P$ $<0.10$ were considered as a trend toward significance. Data are presented as least squares means.

\section{RESULTS AND DISCUSSION}

Feed DMI and milk yield and composition data are shown in Table 2. Treatments had no effects on DMI and milk yield. Compared with MO, CEC increased $(P$ $=0.04$ ) feed efficiency, but had no effect on ECM feed efficiency. Milk composition (milk fat, true protein, and lactose), milk $\mathrm{NE}_{\mathrm{L}}, \mathrm{MUN}, \mathrm{SCC}$, and $\mathrm{BW}$ were also not affected by treatment. Treatments had no effect on milk fatty acid profile (Table 3 ).

Studies examining the effects of CIN, EUG, and CAP on productivity in beef and dairy cattle are scarce and results have been conflicting. Yang et al. (2010b) observed increases in DMI and ADG with 400, 800, and $1,600 \mathrm{mg} /$ head per day of CIN in beef cattle. A blend of $3 \mathrm{PN}$ (CIN, EUG, and CAP; $800 \mathrm{mg}$ /head per day) increased ADG in a study using beef cattle (Compiani et al., 2013). In dairy cows, CAP increased milk yield or feed efficiency (Oh et al., 2015; Stelwagen et al., 2016; Oh et al., 2017b). Oguey and Wall (2016) reported that milk yield was higher for cows fed the same blend used in the current study (CEC); however, other studies reported no effects of CIN, EUG, or CAP on productivity in ruminants. For instance, dietary supplementation of CIN ( $1 \mathrm{~g} / \mathrm{d}$ or $50 \mathrm{mg} / \mathrm{kg} \mathrm{DM})$ did not affect DMI and milk yield and composition in dairy cows (Benchaar et al., 2008; Benchaar, 2016). No effects of EUG were observed on ADG and milk yield in studies with beef and dairy cattle, respectively (Yang et al., 2010c; Benchaar et al., 2012, 2015). Tager and Krause (2011) and Tekippe et al. (2013) observed no effect on productivity of cows fed a blend of $17 \%$ CIN and $28 \%$ 
OH ET AL.

Table 3. Effect of phytonutrients on milk fatty acids (g/100 g of total fatty acids) in dairy cows

\begin{tabular}{|c|c|c|c|c|c|}
\hline \multirow[b]{2}{*}{ Item } & \multicolumn{3}{|c|}{ Treatment $^{1}$} & \multirow[b]{2}{*}{$\mathrm{SEM}^{2}$} & \multirow{2}{*}{$\frac{P \text {-value }}{\text { Treatment }}$} \\
\hline & $\mathrm{MO}$ & MOCAP & CEC & & \\
\hline $4: 0$ & 4.07 & 4.52 & 4.00 & 0.199 & 0.16 \\
\hline $6: 0$ & 2.27 & 2.47 & 2.17 & 0.120 & 0.20 \\
\hline 8:0 & 1.26 & 1.38 & 1.18 & 0.071 & 0.14 \\
\hline 10:0 & 2.92 & 3.17 & 2.65 & 0.186 & 0.16 \\
\hline $12: 0$ & 3.26 & 3.47 & 2.91 & 0.205 & 0.16 \\
\hline 14:0 & 10.1 & 10.5 & 9.48 & 0.508 & 0.37 \\
\hline $14: 1$ & 0.72 & 0.75 & 0.62 & 0.042 & 0.11 \\
\hline $15: 0$ & 0.86 & 0.97 & 0.82 & 0.055 & 0.15 \\
\hline $16: 0$ & 23.4 & 25.8 & 23.1 & 1.05 & 0.16 \\
\hline $16: 1$ & 0.89 & 0.93 & 0.89 & 0.054 & 0.80 \\
\hline $17: 0$ & 0.41 & 0.44 & 0.41 & 0.020 & 0.45 \\
\hline 18:0 & 10.9 & 11.4 & 11.0 & 0.60 & 0.82 \\
\hline $18: 1$ trans -4 & 0.03 & 0.03 & 0.03 & 0.002 & 0.37 \\
\hline $18: 1$ trans -5 & 0.02 & 0.02 & 0.02 & 0.001 & 0.47 \\
\hline $18: 1$ trans $-6-8$ & 0.29 & 0.32 & 0.30 & 0.018 & 0.46 \\
\hline 18:1 trans -9 & 0.24 & 0.27 & 0.23 & 0.014 & 0.21 \\
\hline 18:1 trans -10 & 0.50 & 0.53 & 0.49 & 0.036 & 0.73 \\
\hline 18:1 trans- 11 & 0.99 & 1.19 & 1.00 & 0.074 & 0.13 \\
\hline 18:1 trans- 12 & 0.50 & 0.59 & 0.50 & 0.035 & 0.11 \\
\hline $18: 1$ cis-9 & 16.2 & 15.7 & 15.8 & 0.65 & 0.86 \\
\hline $18: 1$ cis- 11 & 0.66 & 0.70 & 0.68 & 0.045 & 0.85 \\
\hline $18: 2$ cis -9, cis -12 & 3.09 & 3.17 & 3.00 & 0.159 & 0.77 \\
\hline 20:0 & 0.12 & 0.13 & 0.12 & 0.006 & 0.77 \\
\hline $18: 3$ & 0.28 & 0.40 & 0.38 & 0.055 & 0.24 \\
\hline CLA cis-9,trans-11 & 0.45 & 0.49 & 0.42 & 0.034 & 0.39 \\
\hline$\Sigma$ trans fatty acids & 2.56 & 2.88 & 2.56 & 0.172 & 0.33 \\
\hline$\Sigma$ MUFA & 21.0 & 21.2 & 20.6 & 0.90 & 0.90 \\
\hline$\Sigma$ PUFA & 3.81 & 4.06 & 3.81 & 0.195 & 0.59 \\
\hline trans $-10+$ trans -11 & 1.49 & 1.68 & 1.49 & 0.108 & 0.33 \\
\hline trans $-10 \div$ trans $-11^{3}$ & 0.51 & 0.46 & 0.49 & 0.027 & 0.37 \\
\hline
\end{tabular}

EUG. It is likely that differences in chemical properties of active compounds, doses, and animal species resulted in different responses among studies. Production effects of $\mathrm{PN}$ have been compared with those of MO because of the initial dogma that PN may act as natural rumen modifiers (Calsamiglia et al., 2007). A mixture of CIN and EUG (400 mg/head per day) increased ADG compared with MO in steers with no effect on DMI (Geraci et al., 2012). In dairy cows, however, Benchaar (2016) reported that CIN (50 mg/ $\mathrm{kg}$ of dietary DM) did not affect DMI or milk yield and composition compared with $\mathrm{MO}(24 \mathrm{mg} / \mathrm{kg}$ of DM). This is in accordance with a recent study by Chapman et al. (2017), where CIN (1 and $2 \mathrm{mg} / \mathrm{kg}$ of BW) had no effects on DMI or ADG relative to $\mathrm{MO}(1 \mathrm{mg} / \mathrm{kg}$ of $\mathrm{BW})$ in dairy heifers. In the current study, we found no difference between PN and MO in milk yield. The increased feed efficiency by CEC may be an artifact of the nonsignificant decrease in DMI in that treatment compared with MO. The lack of treatment effect on milk fatty acids in our study is in agreement with other reports with $\mathrm{PN}$. Benchaar et al. (2015), for example, reported that feeding EUG (50 $\mathrm{mg} / \mathrm{kg}$ of DMI) did not affect milk fatty acids in dairy cows. Dietary supplementation of CIN and CAP also had no or minor effects on milk fatty acids in dairy cows (Benchaar and Chouinard, 2009; Oh et al., 2015).

Concentrations of blood fatty acids and BHB were similar among treatments (Table 4). Compared with MO, MOCAP tended to increase $(P=0.09)$ the expression of HSL in adipose tissue of the tail region (Figure 1).

The lack of treatment effects on blood fatty acids and $\mathrm{BHB}$ in the current experiment meant that PN did not affect fat mobilization compared with MO. Capsaicin and CIN reportedly increased fat mobilization in studies with nonruminants (Azhar et al., 2016). In dairy cows, dietary supplementation of CAP increased blood BHB or fatty acid concentration (Oh et al., 2015, 2017b) without affecting ruminal fermentation and DMI. The effects of CIN, EUG, or CAP on fat mobi- 


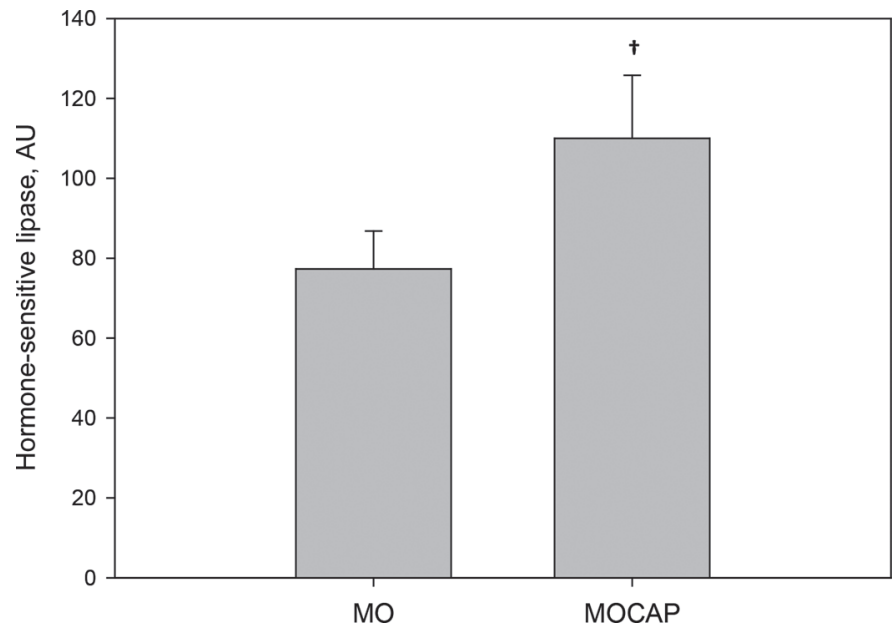

Figure 1. Effect of capsicum on hormone sensitive lipase (mean $\pm \mathrm{SE}$ ) in adipose tissue of the tail head region in dairy cows. $\mathrm{MO}=$ $450 \mathrm{mg} / \mathrm{d}$ of monensin; MOCAP $=450 \mathrm{mg} / \mathrm{d}$ of $\mathrm{MO}$ and $250 \mathrm{mg} / \mathrm{d}$ of capsicum. Results are expressed in arbitrary units (AU). Overall effect of treatment $(\mathrm{n}=24 ; \mathrm{n}$ represents number of observations used in the statistical analysis). $\dagger P=0.09, \mathrm{MO}$ vs. MOCAP.

lization, however, have not been consistent in studies with ruminants. Supplementation of CIN (400 to 1,600 $\mathrm{mg} / \mathrm{d}$ per head) quadratically decreased blood fatty acid concentration in steers and beef heifers, probably due to higher energy supply from increased DMI (Yang et al., 2010a,b). The same amount of EUG (400 to 1,600 $\mathrm{mg} / \mathrm{d}$ per head), however, did not affect blood fatty acids in beef heifers (Yang et al., 2010c). Calsamiglia et al. (2009) used the same mixture (17\% EUG, $11 \%$ CIN, and $7 \%$ CAP) as CEC in the current study and observed decreased blood fatty acids only in prepartum dairy goats. Interestingly, MOCAP slightly increased the expression of HSL in adipose tissue compared with MO in the current study. As an intracellular lipase, HSL hydrolyzes triglycerides into fatty acids (Lampidonis et al., 2011); it is one of the main regulators for lipolysis of adipose tissue and is inhibited by insulin.

Table 4. Effect of phytonutrients on blood concentrations of fatty acids and BHB in dairy cows

\begin{tabular}{lcccccc}
\hline & \multicolumn{3}{c}{ Treatment $^{1}$} & & $P$-value \\
\cline { 2 - 4 } Item & MO & MOCAP & CEC & SEM $^{2}$ & Treatment \\
\hline Fatty acids, & 100 & 98.6 & 97.1 & 4.70 & 0.86 \\
$\mu M$ & 397 & 432 & 433 & 20.6 & 0.33 \\
\hline BHB,$\mu M$ & 397 &
\end{tabular}

${ }^{1} \mathrm{MO}=450 \mathrm{mg} / \mathrm{d}$ of monensin; MOCAP $=450 \mathrm{mg} / \mathrm{d}$ of $\mathrm{MO}$ and 250 $\mathrm{mg} / \mathrm{d}$ of capsicum; $\mathrm{CEC}=1,000 \mathrm{mg} / \mathrm{d}$ of a blend of cinnamaldehyde, eugenol, and capsicum.

${ }^{2}$ Highest SEM shown; $\mathrm{n}=72$ for all variables ( $\mathrm{n}$ represents number of observations used in the statistical analysis).
Reports have shown that CAP and capsaicin decreased blood insulin concentration in rats and humans (Ahuja et al., 2006; van de Wall et al., 2006). In dairy cows, dietary supplementation of rumen protected CAP (100 and $200 \mathrm{mg} / \mathrm{d}$ per cow) decreased insulin concentration (Oh et al., 2017b). Therefore, it is possible that CAP stimulated HSL by decreasing insulin concentration in the current study, although this cannot be confirmed because insulin was not analyzed.

Counts of total white blood cells, neutrophils, lymphocytes, eosinophils, and basophils were not affected by treatment (Table 5). Percentages of neutrophils, lymphocytes, eosinophils, and basophils to total white blood cells were also not affected by treatment. Monocyte count tended to decrease $(P=0.10)$ for CEC compared with MO. White blood cell counts in the current study were within the normal ranges for dairy cows, which are 4,000 to $12,000,600$ to $4,100,2,500$ to 7,500 , 0 to 1,200 , and 0 to 2,400 cells $/ \mu \mathrm{L}$ for total white blood cells, neutrophils, lymphocytes, monocytes, and eosinophils, respectively (Kramer, 2000). Red blood cells, hemoglobin concentration, and platelets were similar among treatments.

Monocytes are a type of white blood cells and account for 2 to $7 \%$ of total white blood cells in cattle (Jones and Allison, 2007). Peripheral monocytes enter the tissues and differentiate into macrophages, the main scavenger cells of the immune system, at the time of bacterial infection (Ginhoux and Jung, 2014). In the current study, CEC tended to decrease monocyte count compared with MO. Studies have reported regulatory effects of CIN, EUG, and CAP on monocytes and macrophages. In nonruminants, CIN exhibited anti-inflammatory responses by decreasing inflammatory cytokines such as IL-1 and tumor necrosis factor produced by murine macrophages (Chao et al., 2005, 2008). Liu et al. (2012) showed that tumor necrosis factor was inhibited by CIN and EUG in porcine macrophages with or without immune stimulators. Dietary supplementation of CAP decreased macrophages count in pigs infected with Escherichia coli (Liu et al., 2013). Phytonutrients are known to activate transient receptor potential channels expressed on neurons, intestinal epithelium, and immune cells (Holzer, 2011). In mammals, transient receptor potential channels act as secondary transducers of cell activation. These physiological effects of PN may also take place in ruminants if PN bypass the rumen. Phenolic PN were reported to be resistant to microbial degradation. Franz et al. (2010) reported in a continuous culture study that some phenolic PN showed recovery rates of up to $60 \%$ after $12 \mathrm{~h}$ of in vitro incubation. In addition, Oh et al. (2016) reported rumen escape rates for capsaicin of 15 to $33 \%$ depend- 
Table 5. Effect of phytonutrients on blood cells in dairy cows

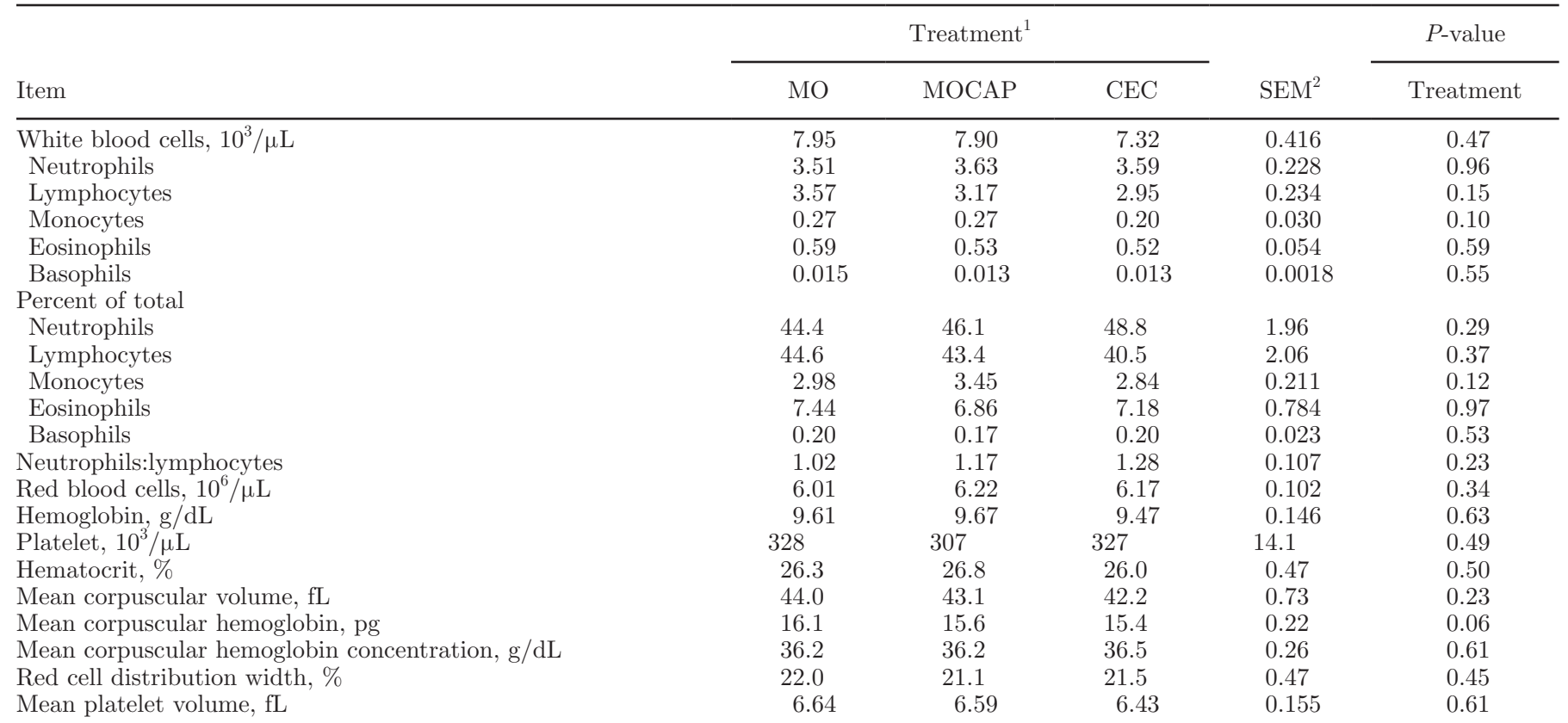

${ }^{1} \mathrm{MO}=450 \mathrm{mg} / \mathrm{d}$ of monensin; MOCAP $=450 \mathrm{mg} / \mathrm{d}$ of $\mathrm{MO}$ and $250 \mathrm{mg} / \mathrm{d}$ of capsicum; CEC = 1,000 mg/d of a blend of cinnamaldehyde, eugenol, and capsicum.

${ }^{2}$ Highest SEM shown; $\mathrm{n}=70$ for all variables ( $\mathrm{n}$ represents number of observations used in the statistical analysis).

ing on the dose. In the current study, CEC decreased monocytes count possibly through regulatory effects in the intestine, although the amount of CEC delivered into the intestines was not assessed. This result suggests that supplementation of CEC may alleviate excessive monocytosis caused by bacterial infection in dairy cows (Roland et al., 2014). It should be noted that cows in the current study were not immunologically challenged; immune cells may respond to PN differently when they are challenged by activation molecules, such as LPS (Liu et al., 2012; Oh et al., 2017c). In other studies with ruminants, however, CIN, EUG, and CAP did not affect monocytes. Supplementation of CIN and EUG $(400,800$, and $1,600 \mathrm{mg} / \mathrm{d}$ per head) in growing beef cattle had no effect on monocyte count (Yang et al., 2010a,c). Several studies with dairy cows showed that CAP did not affect monocytes (Oh et al., 2013, 2015, 2017c); further research on PN effects on monocytes and rumen bypass rates of $\mathrm{PN}$ is warranted.

\section{CONCLUSIONS}

In this study, milk yield, milk composition, or feed efficiency of dairy cows was not affected by supplementation of CAP to a diet that contained MO. Similarly, a blend of PN (CEC) also had no effect on the lactation performance of the cows, except feed efficiency was increased when compared with MO. Subtle increases in blood monocytes count and HSL suggest possible postruminal effects of PN. Further research should investigate rumen bypass rates and potential postruminal effects of phenolic PN in dairy cows.

\section{ACKNOWLEDGMENTS}

The authors thank Pancosma S.A. (Geneva, Switzerland) for providing partial financial support for this project, Centralized Biological Laboratory at The Pennsylvania State University for blood cell counts, and the staffs of The Pennsylvania State University's Dairy Teaching and Research Center for their conscientious care of the experimental cows.

\section{REFERENCES}

Ahuja, K. D., I. K. Robertson, D. P. Geraghty, and M. J. Ball. 2006. Effects of chili consumption on postprandial glucose, insulin, and energy metabolism. Am. J. Clin. Nutr. 84:63-69.

AOAC International. 2000. Official Methods of Analysis. 17th ed. AOAC International, Arlington, VA.

AOAC International. 2006. Official Methods of Analysis. 18th ed. AOAC International, Arlington, VA.

Aschenbach, J. R., N. B. Kristensen, S. S. Donkin, H. M. Hammon, and G. B. Penner. 2010. Gluconeogenesis in dairy cows: The secret of making sweet milk from sour dough. IUBMB Life 62:869-877.

Azhar, Y., A. Parmar, C. N. Miller, J. S. Samuels, and S. Rayalam. 2016. Phytochemicals as novel agents for the induction of browning in white adipose tissue. Nutr. Metab. (Lond.) 13:89. 
Benchaar, C. 2016. Diet supplementation with cinnamon oil, cinnamaldehyde, or monensin does not reduce enteric methane production of dairy cows. Animal 10:418-425.

Benchaar, C., and P. Y. Chouinard. 2009. Short communication: Assessment of the potential of cinnamaldehyde, condensed tannins, and saponins to modify milk fatty acid composition of dairy cows1. J. Dairy Sci. 92:3392-3396.

Benchaar, C., F. Hassanat, and H. V. Petit. 2015. Dose-response to eugenol supplementation to dairy cow diets: Methane production, $\mathrm{N}$ excretion, ruminal fermentation, nutrient digestibility, milk production, and milk fatty acid profile. Anim. Feed Sci. Technol. 209:51-59.

Benchaar, C., A. Lettat, F. Hassanat, W. Z. Yang, R. J. Forster, H. V. Petit, and P. Y. Chouinard. 2012. Eugenol for dairy cows fed low or high concentrate diets: Effects on digestion, ruminal fermentation characteristics, rumen microbial populations and milk fatty acid profile. Anim. Feed Sci. Technol. 178:139-150.

Benchaar, C., T. A. McAllister, and P. Y. Chouinard. 2008. Digestion, ruminal fermentation, ciliate protozoal populations, and milk production from dairy cows fed cinnamaldehyde, quebracho condensed tannin, or yucca schidigera saponin extracts. J. Dairy Sci. 91:4765-4777.

Calsamiglia, S., S. Cavini, A. Bouattour, A. Ferret, and D. Bravo. 2009. Essential oils may reduce the risk of ketosis in dairy goats carrying twins. J. Dairy Sci. 92(E-Suppl. 1):375. (Abstr)

Calsamiglia, S., M. Busquet, P. W. Cardozo, L. Castillejos, and A. Ferret. 2007. Invited review: Essential oils as modifiers of rumen microbial fermentation. J. Dairy Sci. 90:2580-2595.

Cardozo, P. W., S. Calsamiglia, A. Ferret, and C. Kamel. 2006. Effects of alfalfa extract, anise, capsicum, and a mixture of cinnamaldehyde and eugenol on ruminal fermentation and protein degradation in beef heifers fed a high-concentrate diet. J. Anim. Sci. 84:2801-2808.

Chao, L. K., K.-F. Hua, H.-Y. Hsu, S.-S. Cheng, I. F. Lin, C.-J. Chen, S.-T. Chen, and S.-T. Chang. 2008. Cinnamaldehyde inhibits proinflammatory cytokines secretion from monocytes/macrophages through suppression of intracellular signaling. Food Chem. Toxicol. 46:220-231.

Chao, L. K., K.-F. Hua, H.-Y. Hsu, S.-S. Cheng, J.-Y. Liu, and S.-T. Chang. 2005. Study on the antiinflammatory activity of essential oil from leaves of Cinnamomum osmophloeum. J. Agric. Food Chem. 53:7274-7278.

Chapman, C. E., H. Chester-Jones, D. Ziegler, J. A. Clapper, and P. S. Erickson. 2017. Effects of cinnamaldehyde or monensin on performance of weaned Holstein dairy heifers. J. Dairy Sci. 100:17121719.

Compiani, R., C. A. Sgoifo Rossi, A. Pizzi, and V. Dell'Orto. 2013. Administration of essential oils cinnamaldehyde, eugenol, and capsicum to beef cattle: Effects on health status and growth performance. Pages 177-180 in Trends in Veterinary Sciences: Current Aspects in Veterinary Morphophysiology, Biochemistry, Animal Production, Food Hygiene and Clinical Sciences. C. Boiti, A. Ferlazzo, A. Gaiti, and A. Pugliese, ed. Springer Berlin Heidelberg, Berlin, Heidelberg.

Cowan, M. M. 1999. Plant products as antimicrobial agents. Clin. Microbiol. Rev. 12:564-582.

Franz, C., K. H. C. Baser, and W. Windisch. 2010. Essential oils and aromatic plants in animal feeding-A European perspective. A review. Flavour Fragrance J. 25:327-340.

Geraci, J. I., A. D. Garciarena, G. A. Gagliostro, K. A. Beauchemin, and D. Colombatto. 2012. Plant extracts containing cinnamaldehyde, eugenol and capsicum oleoresin added to feedlot cattle diets: Ruminal environment, short term intake pattern and animal performance. Anim. Feed Sci. Technol. 176:123-130.

Ginhoux, F., and S. Jung. 2014. Monocytes and macrophages: Developmental pathways and tissue homeostasis. Nat. Rev. Immunol. 14:392-404.

Holzer, P. 2011. Transient receptor potential (trp) channels as drug targets for diseases of the digestive system. Pharmacol. Ther. 131:142-170.
Janssen, P. H. 2010. Influence of hydrogen on rumen methane formation and fermentation balances through microbial growth kinetics and fermentation thermodynamics. Anim. Feed Sci. Technol. $160: 1-22$.

Jones, M. L., and R. W. Allison. 2007. Evaluation of the ruminant complete blood cell count. Vet. Clin. North Am. Food Anim. Pract. 23:377-402.

Kramer, J. W. 2000. Normal hematology of cattle, sheep, and goats. Pages 1075-1084 in Schalm's Veterinary Hematology. B. Feldman, J. Zinkl, and N. Jain, ed. Lippincott, Philadelphia, PA.

Lampidonis, A. D., E. Rogdakis, G. E. Voutsinas, and D. J. Stravopodis. 2011. The resurgence of hormone-sensitive lipase (HSL) in mammalian lipolysis. Gene 477:1-11.

Lee, S. H., H. S. Lillehoj, S. I. Jang, K. W. Lee, D. Bravo, and E. P. Lillehoj. 2011. Effects of dietary supplementation with phytonutrients on vaccine-stimulated immunity against infection with Eimeria tenella. Vet. Parasitol. 181:97-105.

Liu, Y., M. Song, T. M. Che, J. A. Almeida, J. J. Lee, D. Bravo, C. W. Maddox, and J. E. Pettigrew. 2013. Dietary plant extracts alleviate diarrhea and alter immune responses of weaned pigs experimentally infected with a pathogenic Escherichia coli. J. Anim. Sci. 91:5294-5306.

Liu, Y., M. Song, T. M. Che, D. Bravo, and J. E. Pettigrew. 2012. Anti-inflammatory effects of several plant extracts on porcine alveolar macrophages in vitro. J. Anim. Sci. 90:2774-2783.

NRC. 2001. Nutrient Requirements of Dairy Cattle. 7th rev. ed. Natl. Acad. Sci., Washington, DC.

Oguey, C., and E. H. Wall. 2016. A blend of cinnamaldehyde, eugenol, and capsicum oleoresin improves milking performance in lactating dairy cows. J. Dairy Sci. 99(Suppl. 1):750. (Abstr.)

Oh, J., D. M. Bravo, E. H. Wall, and A. N. Hristov. 2016. Rumen disappearance of capsaicin and dihydrocapsaicin in lactating dairy cows. J. Dairy Sci. 99(E-Suppl. 1):788. (Abstr.)

Oh, J., F. Giallongo, T. Frederick, J. Pate, S. Walusimbi, R. J. Elias, E. H. Wall, D. Bravo, and A. N. Hristov. 2015. Effects of dietary capsicum oleoresin on productivity and immune responses in lactating dairy cows. J. Dairy Sci. 98:6327-6339.

Oh, J., M. Harper, F. Giallongo, D. M. Bravo, E. H. Wall, and A. N. Hristov. 2017b. Effects of rumen-protected capsicum oleoresin on productivity and responses to a glucose tolerance test in lactating dairy cows. J. Dairy Sci. 100:1888-1901.

Oh, J., M. Harper, F. Giallongo, D. M. Bravo, E. H. Wall, and A. N. Hristov. 2017c. Effects of rumen-protected capsicum oleoresin on immune responses in dairy cows intravenously challenged with lipopolysaccharide. J. Dairy Sci. 100:1902-1913.

Oh, J., A. N. Hristov, C. Lee, T. Cassidy, K. Heyler, G. A. Varga, J. Pate, S. Walusimbi, E. Brzezicka, K. Toyokawa, J. Werner, S. S. Donkin, R. Elias, S. Dowd, and D. Bravo. 2013. Immune and production responses of dairy cows to postruminal supplementation with phytonutrients. J. Dairy Sci. 96:7830-7843.

Oh, J., E. H. Wall, D. M. Bravo, and A. N. Hristov. 2017a. Hostmediated effects of phytonutrients in ruminants: A review. J. Dairy Sci. 100:5974-5983.

Patra, A. K. 2012. Dietary Phytochemicals and Microbes. Springer, New York, NY.

Rico, D. E., and K. J. Harvatine. 2013. Induction of and recovery from milk fat depression occurs progressively in dairy cows switched between diets that differ in fiber and oil concentration. J. Dairy Sci. 96:6621-6630.

Roland, L., M. Drillich, and M. Iwersen. 2014. Hematology as a diagnostic tool in bovine medicine. J. Vet. Diagn. Invest. 26:592-598.

Russell, J. B., and H. J. Strobel. 1989. Effect of ionophores on ruminal fermentation. Appl. Environ. Microbiol. 55:1-6.

Sjaunja, L. O., L. Baevre, L. Junkkarinen, J. Pedersen, and J. Setälä. 1990. A Nordic proposal for an energy corrected milk (ECM) formula. Pages 156-157 in 27th Session of the International Commission for Breeding and Productivity of Milk Animals, Paris, France. Wageningen Academic Publishers, Wageningen, the Netherlands.

Smith, D. J., and J. P. McNamara. 1989. Lipolytic response of bovine adipose tissue to alpha and beta adrenergic agents 30 days preand 120 days postpartum. Gen. Pharmacol. 20:369-374. 
Srinivasan, K. 2016. Biological activities of red pepper (Capsicum annuum) and its pungent principle capsaicin: A review. Crit. Rev. Food Sci. Nutr. 56:1488-1500.

Stelwagen, K., E. H. Wall, and D. M. Bravo. 2016. Effect of rumenprotected capsicum on milk production in early lactating cows in a pasturebased system. J. Dairy Sci. 99(E-Suppl. 1):664. (Abstr)

Tager, L. R., and K. M. Krause. 2011. Effects of essential oils on rumen fermentation, milk production, and feeding behavior in lactating dairy cows. J. Dairy Sci. 94:2455-2464.

Tekippe, J. A., R. Tacoma, A. N. Hristov, C. Lee, J. Oh, K. S. Heyler, T. W. Cassidy, G. A. Varga, and D. Bravo. 2013. Effect of essential oils on ruminal fermentation and lactation performance of dairy cows. J. Dairy Sci. 96:7892-7903.

van de Wall, E. H., P. Y. Wielinga, J. H. Strubbe, and G. van Dijk. 2006. Neonatal capsaicin causes compensatory adjustments to energy homeostasis in rats. Physiol. Behav. 89:115-121.
Van Soest, P. J., J. B. Robertson, and B. A. Lewis. 1991. Methods for dietary fiber, neutral detergent fiber, and nonstarch polysaccharides in relation to animal nutrition. J. Dairy Sci. 74:3583-3597.

Yang, W. Z., B. N. Ametaj, C. Benchaar, and K. A. Beauchemin. 2010a. Dose response to cinnamaldehyde supplementation in growing beef heifers: Ruminal and intestinal digestion. J. Anim. Sci. $88: 680-688$

Yang, W. Z., B. N. Ametaj, C. Benchaar, M. L. He, and K. A. Beauchemin. 2010b. Cinnamaldehyde in feedlot cattle diets: Intake, growth performance, carcass characteristics, and blood metabolites. J. Anim. Sci. 88:1082-1092.

Yang, W. Z., C. Benchaar, B. N. Ametaj, and K. A. Beauchemin. 2010c. Dose response to eugenol supplementation in growing beef cattle: Ruminal fermentation and intestinal digestion. Anim. Feed Sci. Technol. 158:57-64 